\title{
Title:
}

\section{Corporal Punishment in Schools in the Jaffna District of Sri Lanka - A students' view}

Sathiadas, M G (MD, MRCPCH) (Corresponding Author)

Department of Paediatrics, University of Jaffna

PO Box: 57, Adiyapatham Raod, Jaffna, Sri Lanka

Phone: +94777598062/+94212220378

Email: docsathiadas@hotmail.com

ORCid: $\underline{0000-0002-7822-0447}$

Annieston Antonyraja (MBBS)

Department of Paediatrics

PO Box: 57, Adiyapatham Raod, Jaffna, Sri Lanka

Email: a.annieston@gmail.com

ORCid:0000-0001-5450-0084

Arunath Viswalingam (MBBS)

Department of Paediatrics

PO Box: 57, Adiyapatham Raod, Jaffna, Sri Lanka

Email: arunkarthi91@gmail.com

ORCid:0000-0002-7705-0394

Shubanki Arunthavavinajagamoorthy (MBBS)

Department of Paediatrics

PO Box: 57, Adiyapatham Raod, Jaffna, Sri Lanka

Email: shubanky@gmail.com

ORCid:0000-0002-1773-1681 


\section{Introduction}

Corporal punishment is a method to discipline a child where an adult deliberately inflicts pain upon a child in response to a child's unacceptable behaviour and instil discipline. The long-term aim is to prevent the recurrence of the bad behaviour and be consistent with the adult's expectations [1].

Corporal punishment (CP) in the name of "discipline" continues in homes, schools, childcare institutions and juvenile detention centres [2]. Legal protection is given to children to protect them from corporal punishment and to ensure human rights. Almost $95 \%$ of the world's total child population live in countries which lack a legal system to protect children and $29.3 \%$ live in South Asia. Nearly $55.7 \%$ of children live in countries that have no law to protect children from corporal punishment and $50.0 \%$ of them live in South Asia [3].

Both children and adults believe that CP is an effective way of discipline [4]. Many studies have shown the opposite by showing the detrimental effects of CP [5]. Some of them are poor academic performance, low level of class participation, avoiding school or dropping out for fear of getting beaten, declining self-worth or self-esteem and fear of teachers and school [6,7]. Prospective and meta-analysis have concluded that spanking fails to change the child's behaviour but can cause longterm damage [8]. Physically abused children have an increased chance of developing depression, become more aggressive, behave antisocially and develop anxiety [9]. A study done in Sri Lanka in 2008 also showed that parental corporal punishment is associated with psychological harm in children $[10]$.

Physical punishment used by an authoritative figure teaches violence as a method of correction and this can hinder parent-child relationship and other relationships $[11,12]$. CP is partly blamed as an aetiology for criminal violence in youth hence it must be addressed as a preventive step [13].

The United Nations declared universal prohibition of corporal punishment in 2006. [14]. Global Initiative to end corporal punishment has been helping to mobilise and support nations to change their laws and social attitudes [15]. Sri Lanka expressed its commitment to prohibit corporal punishment at 
home and schools in July 2006, which was reiterated in 2017. Even though the instruction was adopted by a government circular, it is been confirmed through the enactment of legislation $[16,17]$.

Reporting and maintaining data on corporal punishment is vital to initiate preventive strategies. CP is likely to be under-reported as the victims are afraid of repercussions [7]. Unconfirmed reports say that most of the schools still practice $\mathrm{CP}$ and conventionally believe that mild $\mathrm{CP}$ is acceptable and necessary to discipline children [18]. There are few studies done regarding the prevalence of CP but very few regarding the knowledge and perception among the school children. Knowledge regarding $\mathrm{CP}$ is vital to understand the importance and the long term detrimental effect [19].

School children and teachers should be aware of CP and should take measure to prevent it. We conducted this study among school children to see the knowledge, perception, and actions the students would take towards $\mathrm{CP}$. The objective of this study was to identify the prevalence of $\mathrm{CP}$, factors that influence $\mathrm{CP}$, their knowledge, its long-term effect on their wellbeing and the perception towards $\mathrm{CP}$.

\section{Materials and Methods:}

\section{Setting}

A community based cross sectional descriptive study was done among 16-19y studying in both private and government schools in the Jaffna district, Sri Lanka. The study period was July to August 2018. The sample size was calculated using the expected proportion of children experiencing corporal punishment being 50\% with $95 \%$ confidence interval. To cluster design effect (DE) was considered as 1.8 ; and a non-repose rate of $5 \%$. [20].

\section{Sampling}

Multistage stratified proportionate cluster sampling was done, and ten schools located in the district of Jaffna were selected using a recently updated list of secondary schools in the district of Jaffna with a probability proportionate to the size of student population. Within each selected school, five classes 
were selected as the clusters to cover the different streams. A classroom comprising 20-30 students was considered as a cluster. The entire class that was considered as a cluster was sampled.

\section{Study tool}

An anonymous pre-tested and standardised self-administered questionnaire was used. A field test was conducted with 10 experts in the field of child abuse to measure the content validity. The questionnaire was modified as per the expert suggestions, and the modified version was used as the study tool.

To assess the knowledge, questions regarding types of corporal punishments, the reason for the punishment and the legal implications were checked. A set of 17-items which had correct and incorrect responses were used, and each correct response was awarded +1 . A score $\geq 13$ was considered as good knowledge.

The perception towards CP was checked with another 22 items which recorded the response on the likert scale and the responses were recorded as "strongly agree" or "agree", or "somewhat agree" or "disagree", or "strongly disagree". Depending on whether it was a proper attitude or not, scores from 1 to 5 were allotted. Reverse scoring was awarded for the negative responses. A score of ' 0 ' was given for "don't know"/ "can't say". A score of $>85$ was the considered as an overall good perception, 60-85 considered a more positive perception and $<60$ considered as needing a change in the perception.

The questionnaire also checked the preferred method of discipline and the outcome of CP in those who received it.

\section{Data analysis}

Data was analysed by using Statistical Package for Social Sciences (SPSS) version 22.0. Responses were expressed as percentage and Chi-square test for significance of difference among proportions was calculated. Analysis of variance for significance of difference among means was calculated and Cronbach alpha was used to assess the reliability of the scores. The data was described using 
frequencies and percentages. One-way ANOVA was used to compare the means of the scores for perception and knowledge. $\mathrm{P}$ value of $<0.05$ was considered as statistically significant.

Ethical approval was obtained from the Ethics Review Committee of the University of Jaffna $(J / E R C / 16 / 72 / N D R / 0143)$ and permission was sought from the Provincial Educational authorities.

\section{Results:}

A total population of 1130 was recruited to the study. Majority were boys (53.5\%) and mean age was $17.58 \pm 0.5 y$. (Table 1) Nearly $60.7 \%$ (687) had experienced at least one episode of punishment either at home or school during a school term. Physical type was experienced by $64.5 \%(\mathrm{n}=443)$ followed by psychological seen in $27.1 \%(\mathrm{n}=186)$ and both forms in $8.4 \%(\mathrm{n}=58)$. Table 2 describes the number of incidences, the reason for $\mathrm{CP}$ and type of $\mathrm{CP}$ the child received. There was no significant relationship between age, sex, stream of study, family type, number of siblings and socio-economic status to the incidences of $\mathrm{CP}$ ( $\mathrm{p}$ value $>0.05)$. The students who received $\mathrm{CP}$ reported that the teachers $(86.9 \%)$ were the main group inflicting CP followed by parents $(74 \%)$, elder siblings $(28 \%)$ and other elders in the community (10.3\%).

The common form of physical punishment was beating with a stick or hand experienced by $46.6 \%$ $(\mathrm{n}=527)$. The common form of psychological CP was being called names $(20.8 \%)$ followed by shouted and yelled (19.8\%). (Table 3)

Some forms of punishments that the students experienced were perceived as favourable to them such as getting extra homework in $58 \%(n=655)$, after school class in $38 \%(n=429)$, cleaning the school and grounds experienced by $23 \%(n=260)$, removal of privileges in $29 \%(n=328)$ and when the teacher/parent explained and gave advice in $47 \%(\mathrm{n}=531)$

Nearly $7.3 \%(n=82)$ of the children received medical treatment following an injury due to CP. Of the students who received CP, $60.4 \%(n=415)$ said it did not change or affect them, $18.6 \%(n=128)$ said it 
changed their behaviour and 9.0\% $(n=62)$ said it affected them psychologically as they felt sad and rejected.

The mean score for the knowledge component was $11.2 \pm 3.2$. There was a significant difference in the mean score for knowledge between boys and girls. $85 \%$ of the students knew the child's right charter and nearly all the children knew the emergency contact number to dial if a harm occurred to them. Table 4 describes the components of knowledge.

The perception of CP indicated a mean population score of $54.9 \pm 14.2$. The scores were not statistically significant between the girls and boys. Nearly $2 \%(n=22)$ had good perception, $40.8 \%(n=461)$ had a more positive perception and $57.3 \%(\mathrm{n}=647)$ needed a perceptual change towards CP. (Table 4)

A total of $38.2 \%(n=432)$ of the participants agree while $27.1 \%(n=306)$ disagree that CP promotes future perpetrators to commit child abuse. Nearly $70.4 \%(n=796)$ of the participants disagreed with the statement " $\mathrm{CP}$ is psychologically beneficial" and $45.9 \%(\mathrm{n}=519)$ agreed that corporal punishment is associated with an increase in delinquent and antisocial behaviours in childhood. It was noted that students marked either strongly agree or agree in $60.7 \%(\mathrm{n}=686)$ to "CP disgraces you", $57.9 \%(\mathrm{n}=654)$ to " $\mathrm{CP}$ causes too much pain and has a detrimental effect", $45.6 \%(n=515)$ to "increases the antisocial and illegal behaviour", $56.7 \%(\mathrm{n}=641)$ to aggressive behaviour and $38.3 \%(\mathrm{n}=50)$ to increases conflicts in the family and leads to gender based violence. The mean scores of each component tested for the study population is indicated in table 5 .

Majority $(86.3 \%)$ preferred an alternative way of discipline and felt corporal punishment had a detrimental effect on their future development $(89.5 \%)$. A total of $31.8 \%(n=359)$ said it was a method used to discipline students and accepted it with reluctance. Nearly $79.6 \%(\mathrm{n}=900)$ answered yes to "will you take legal actions against CP" and 50.5\% (n=571) supported complete prohibition of corporal punishment.

Participants with good knowledge and positive perception favor legal action, support complete prohibition of $\mathrm{CP}$ and felt it had a detrimental effect on their future. (Table 6) 


\section{Discussion:}

Teachers and parents use various tactics to discipline and correct behaviour in children. Despite having legal implications against corporal punishment, schools in the northern part still use it to discipline children. This hinders the long-term developments and is known to cause psychological problems and may lead to criminal behaviour in adult life [9]. Sri Lankan schools thrive to show off their educational and extra-curricular performances. This leads to immense stress in the teachers and parents and thereby it is transmitted to the children. This stress and anxious situation make the adults resort to physically and psychologically harmful methods to make the children perform [21]. In this study also physical and psychological punishments have been predominant when compared to positive methods of discipline. Nearly $65 \%$ have reported having the experience of $\mathrm{CP}$ in our study which is also similar to a study from India which showed $65 \%$ and a study from Sri Lanka stated nearly $80 \%$ have experienced it $[7,20]$. Studies done in India have demonstrated that CP commonly occurs in poor socio-economic background children, but our study did not demonstrate this $[3,7]$.

The reason for CP is mainly physical seen in $64.5 \%(\mathrm{n}=443)$ of the population and when compared to a previous study done in 2017 the incidence was nearly $80 \%$. The awareness created on litigation may have contributed to the reduction in the prevalence from 2017 to our study. The downward trend is promising as the Millennial developmental goal is to end violence against children by 2030 [14].

$\mathrm{CP}$ is known to cause negative effect like physical injuries, poor academic performances, school dropouts, low self-esteem and fear of school and teachers. In our study the short-term harm of physical injury was seen in $7.3 \%$. Despite these effects CP is still advocated by the children and adults. Our study also showed that $31.8 \%(n=359)$ accepted CP despite the knowledge that it had a detrimental effect.

Nearly $36 \%$ of the students have experienced CP at least once during the school term and $7 \%$ have experienced it daily. Of the various modes most common one was beating with the stick or cane experienced by $46.6 \%$ of the students followed by standing outside the class for long time (40.4\%), 
slapping the cheek (32.5\%) and ear squeezing (30\%). Similar types of injuries have been seen in other studies [7. 20]. Most of the children encountered the punishments in school but 27.5\% experienced CP both at home and school. Similar results were seen in other studies [8.20].

Psychological aggression towards the children was noted in $27.1 \%$ and calling by names was the commonest (20.8\%). When compared to other studies this seems to be low and it may be that the students' perception of psychological trauma may be different in different study populations and countries [22].

The knowledge regarding CP was good in $40 \%$ of the girls and $35 \%$ of the boys. The easy access to social media and web may have contributed to the good knowledge and girls generally being more disciplined were better aware of CP than the boys [23].

The perception showed mixed responses as the scoring system showed good and more positive feeling only in $42.7 \%$. and nearly $57 \%$ needed a perceptual change. $608(53.8 \%)$ of the students strongly agreed or agreed to corporal punishment disgraces them. Almost equal percentage of participants said that CP made them to hate studies (47.3\%) and CP encourages them to learn (45.8\%). This may be supported by the cultural belief that the teacher or the parent does this for their betterment [24]. Violence in this culture is accepted and thereby CP becomes acceptable to many. CP leads to higher levels of societal violence, thereby reducing use of corporal punishment should lead to reductions in societal violence. This awareness may help to abolish CP in the future [24].

The action to overcome $\mathrm{CP}$ was promising as most (86.4\%) preferred an alternative method of discipline despite $31.8 \%$ accepting $\mathrm{CP}$ as a mode of discipline. Nearly $89 \%$ felt it was detrimental to their future. Even though most indicated $\mathrm{CP}$ was detrimental and supported complete prohibition they accepted it as a mode to discipline. This may be a cultural impact where the children are taught from early years that the adults inflict harm to correct unacceptable behaviour and to discipline them. [24].

Students with good knowledge and a positive attitude regarding CP, had a clearer plan of action. This shows a promising outlook towards the future. 
To shape desirable behaviour in students and correct misbehaviour disciplinary strategies rather than punishment strategies are required [25]. The power dynamics of adults and the cultural acceptability of CP must be abolished, and alternative approaches must be encouraged. Some of the alternative approaches are non- violent discipline, effective communication and conflict resolution [26]. When Positive discipline is inculcated it promotes appropriate behaviour. Teachers should be made aware of alternatives to corporal punishments in schools to stop the menace of punishing children and making the schools safe [27].

This study is limited to16-18-y-old adolescents and cannot be generalized as younger age groups were not considered. A similar study in teachers and parents will give a better idea regarding the perception which will abolish CP completely.

\section{Conclusion}

Use of corporal punishment is widespread with physical harm being common. The knowledge regarding CP was satisfactory but a change in perception is needed among the school students attending secondary schools in the Northern Province.

\section{DECLARATION}

\section{Funding}

This research did not receive any specific grant from funding agencies in the public, commercial, or not-for-profit sectors.

\section{Conflict of interest}

The authors have declared that they do not have any real or perceived conflict of interests.

\section{Ethics approval}


Ethical approval was obtained from the Ethics Review Committee of the Faculty of Medicine, University of Jaffna $(J / E R C / 16 / 72 / N D R / 0143)$ and permission was sought from the Provincial Educational ministry and relevant zonal directors.

\section{Consent to participate}

Eligible sample of participants were informed and written informed consent from the parent or guardian and accent from the students were obtained. Participants received instructions for opting out of the survey.

\section{Consent for Publication}

Not applicable in this study

\section{Availability of data and materials}

The data in this study is available from the corresponding author on request.

\section{Code availability}

Not applicable to this study

\section{Author contribution}

MGS - Designed and developed the protocol, monitored data collection, reviewed and revised the manuscript and approved the final document, AA - Data collection, analysis and approved the final manuscript, AV - Data Collection, manuscript preparation and approved the final manuscript, SA Data collection, manuscript preparation and approved the final manuscript, All Authors read and approved the final manuscript prior to submission.

\section{List of Abbreviations}

CP: Corporal Punishment, WHO: World Health Organisation, GCE A/L: General Certificate of Education Advanced Level, UNICEF: United Nations Childrens' Fund 


\section{References}

1. Violent discipline. https://data.unicef.org/topic/child-protection/violence/violent-discipline/. Accessed 14-05-2020

2. Christopher J. Ferguson, Spanking, corporal punishment, and negative long-term outcomes: A meta-analytic review of longitudinal studies. Clinical Psychology Review, Volume 33, Issue 1, 2013, Pages 196-208, ISSN 0272-7358, https://doi.org/10.1016/j.cpr.2012.11.002

3. Corporal punishments in schools. Longitudinal Evidence from Ethiopia, India, Peru and Vietnam.

https://www.unicef.irc.org/publications/pdf/CORPORAL\%20PUNISHMENTfinal.pdf. Accessed 15-05-2020

4. Eid Bassam, Touma Boulos Marianne, Lydia Khabbaz Rabbaa \& Bernard Gerbaka (2018) Corporal punishment of children: discipline or abuse?, Libyan Journal of Medicine, 13:1, 1485456, DOI: $10.1080 / 19932820.2018 .1485456$

5. Turner, H. A., \& Muller, P. A. (2004). Long-Term Effects of Child Corporal Punishment on Depressive Symptoms in Young Adults: Potential Moderators and Mediators. Journal of Family Issues, 25(6), 761-782. https://doi.org/10.1177/0192513X03258313

6. Gámez-Guadix, M., Straus, M. A., Carrobles, J. A., Muñoz-Rivas, M. J., \& Almendros, C. (2010). Corporal punishment and long-term behavior problems: The moderating role of positive parenting and psychological aggression. Psicothema, 22(4), 529-536.

7. Morrow, Virginia \& Singh, Renu. (2015). Children's perceptions of punishment in schools in Andhra Pradesh, India. Gender Violence in Poverty Contexts: The Educational Challenge. 6783.

8. Joan Durrant, Ron Ensom, CMAJ Sep 2012, 184 (12) 1373Physical punishment of children: lessons from 20 years of research 1373 -1377; DOI: 10.1503/cmaj.101314

9. Straus, M. (1991). Discipline and Deviance: Physical Punishment of Children and Violence and Other Crime in Adulthood. Social Problems, 38(2), 133-154. doi:10.2307/800524 
10. De Zoysa, P., Newcombe, P.A. and Rajapakse, L., 2008. Consequences of parental corporal punishment on 12-year old children in the Colombo district. Ceylon Medical Journal, 53(1), pp.7-9. DOI: http://doi.org/10.4038/cmj.v53i1.218

11. Lenta, P. (2012). Corporal Punishment of Children. Social Theory and Practice, 38(4), 689716. Retrieved June 9, 2020, from www.jstor.org/stable/23558767

12. Dominique A. Simons, Sandy K. Wurtele, Relationships between parents' use of corporal punishment and their children's endorsement of spanking and hitting other children, Child Abuse \& Neglect, Volume 34, Issue 9, 2010, Pages 639-646, ISSN 0145-2134, https://doi.org/10.1016/j.chiabu.2010.01.012

13. Jennifer E. Lansford, PhD, 2 Sombat Tapanya, PhD, 3 Paul Odhiambo Oburu. Corporal punishment. http://www.child-encyclopedia.com/sites/default/files/textesexperts/en/907/corporal-punishment.pdf. Accessed 02-06-2020

14. MDG goal 2030: https://violenceagainstchildren.un.org/sites/violenceagainstchildren. un.org/files/2030_agenda/sdg leaflet.pdf. pdf. Accessed 20-05-2020

15. Global initiative corporal punishment of children. https://endcorporalpunishment.org/. Accessed 09-06-2020

16. Lucas, G.N., 2014. Corporal punishment in children: The Sri Lankan scenario. Sri Lanka Journal of Child Health, 43(2), pp.71-72. DOI: http://doi.org/10.4038/sljch.v43i2.7002

17. Situation report on Sri Lanka: https://endcorporalpunishment.org/reports-on-every-state-andterritory/sri-lanka/ updated December 2019 Accessed on 15-05-2020

18. Ghosh, Arijit and Pasupathi, Madhumathi, Perceptions of Students and Parents on the Use of Corporal Punishment at Schools in India (September 19, 2016). Available at SSRN: https://ssrn.com/abstract=2840613 or http://dx.doi.org/10.2139/ssrn.2840613

19. Turner, Heather \& Muller, Paul. (2004). Long-Term Effects of Child Corporal Punishment on Depressive Symptoms in Young AdultsPotential Moderators and Mediators. Journal of Family Issues - J FAM ISS. 25. 761-782. 10.1177/0192513X03258313. 
20. Harendra de Silva. A Study on Child Disciplinary Methods Practiced in Schools in Sri Lanka. http://www.childprotection.gov.lk/documents/24.1.2018\%20Disciplinary\%20Methods\%20fin al\%20report\%2006-07-2017.pdf. Accessed 17-05-2020.

21. Feinstein, S., Mwahombela, L. Corporal punishment in Tanzania’s schools. Int Rev Educ 56, 399-410 (2010). https://doi.org/10.1007/s11159-010-9169-5

22. Khamis, V. (2016). Does parent's psychological distress mediate the relationship between war trauma and psychosocial adjustment in children? Journal of Health Psychology, 21(7), 1361-1370. https://doi.org/10.1177/1359105314553962

23. Holden, G. W., Brown, A. S., Baldwin, A. S., \& Caderao, K. C. (2014). Research findings can change attitudes about corporal punishment. Child abuse \& neglect, 38(5), 902-908.

24. Lansford, J. E., \& Dodge, K. A. (2008). Cultural Norms for Adult Corporal Punishment of Children and Societal Rates of Endorsement and Use of Violence. Parenting, science and practice, $8(3), 257-270$. https://doi.org/10.1080/15295190802204843

25. Gerald, N. K., Augustine, M. K., \& Ogetange, T. B. (2012). Teachers and pupils views on persistent use of corporal punishment in managing discipline in primary schools in Starehe Division, Kenya.

26. Canter, L. (1996). Discipline Alternatives. First, the Rapport--Then, the Rules. Learning, 24(5), 12-14.

27. Elizabeth T. Gershoff (2017) School corporal punishment in global perspective: prevalence, outcomes, and efforts at intervention, Psychology, Health \& Medicine, 22:sup1, 224239, DOI: $10.1080 / 13548506.2016 .1271955$ 
Table 1: Socio demography of the study population

\begin{tabular}{|c|c|c|}
\hline Item & Sub category & Number (\%) \\
\hline \multirow{2}{*}{ Mean age } & Girls $(n=525)$ & $17.6 \pm 0.5 \mathrm{yrs}$ \\
\hline & Boys $(n=605)$ & $17.5 \pm 0.5 \mathrm{yrs}$ \\
\hline \multirow{5}{*}{ Stream of study } & Maths & $225(19.9)$ \\
\hline & Science & $294(26.0)$ \\
\hline & Arts & $316(27.9)$ \\
\hline & Commerce & $213(18.8)$ \\
\hline & Information technology & $82(7.3)$ \\
\hline \multirow{3}{*}{ Religion } & Hindus & $870(76.9)$ \\
\hline & Christians & $248(21.9)$ \\
\hline & Muslims & $12(1.0)$ \\
\hline \multirow{4}{*}{ Socio-economic status } & $<$ LKR 15,000 & $321(28.4)$ \\
\hline & LKR $15,000-30,000$ & $585(51.8)$ \\
\hline & $>$ LKR 30,000 & $214(18.9)$ \\
\hline & Do not Know & $10(0.8)$ \\
\hline \multirow{3}{*}{$\begin{array}{l}\text { Number of children in } \\
\text { Family }\end{array}$} & Only child & $198(17.5)$ \\
\hline & 2-3 children & $586(51.9)$ \\
\hline & $>3$ children & $346(30.6)$ \\
\hline \multirow{3}{*}{ Family Type } & Nuclear & $815(72.1)$ \\
\hline & Extended & $233(20.6)$ \\
\hline & Single parent & $82(7.3)$ \\
\hline
\end{tabular}


Table 2: Corporal punishment experienced by the students

\begin{tabular}{|l|l|l|}
\hline Item & Subcategory & Number (\%) \\
\hline Type of Punishment ${ }^{\circledR}(\mathrm{n}=687)$ & Physical & $443(64.5)$ \\
\hline & Psychological & $186(27.1)$ \\
\hline & Mixed & $58(8.4)$ \\
\hline & None & $443(39.2)$ \\
\hline Frequency of experiencing & Daily & $79(7.0)$ \\
\hline & $1-3$ per week & $348(30.8)$ \\
\hline & $1-3$ per month & $268(23.7)$ \\
\hline & Once per term & $409(36.1)$ \\
\hline Place of experiencing the CP & School & $389(56.6)$ \\
\hline & Home & $68(9.9)$ \\
\hline & Community & $41(6.0)$ \\
\hline Reason for the CP $($ Incidences $)$ & School and home & $189(27.5)$ \\
\hline & Academic related & $348(50.6)$ \\
\hline & Discipline related & \\
\hline & Behaviour related & $386(56.2)$ \\
\hline & Reason not clear & $184(26.8)$ \\
\hline & & $67(9.8)$ \\
\hline
\end{tabular}

${ }^{a}$ Academic related: making mistakes, not reading/writing, not doing home work, low marks

${ }^{b}$ Discipline related: coming late, absent, fighting with others, damage to property, being noisy,

${ }^{c}$ Behaviour related: stealing, not getting permission to go out, telling lies, 
Table 3: Prevalence of strategies of punishment

\begin{tabular}{|l|l|}
\hline Type of physical punishment & $\begin{array}{l}\text { Number of } \\
\text { incidences (\%) }\end{array}$ \\
\hline Ear squeezing & $339(30.0)$ \\
\hline Slapping on the cheeks & $367(32.5)$ \\
\hline Asked to kneel-down & $340(30.0)$ \\
\hline Sit ups & $244(21.6)$ \\
\hline Beating with a stick/cane/hand to the lower limbs & $527(46.6)$ \\
\hline Pinching & $235(20.8)$ \\
\hline Stand on the table & $178(15.8)$ \\
\hline Standing on one leg for a long time & $94(8.3)$ \\
\hline Hands-above-the head & $163(14.4)$ \\
\hline Stand outside the class/Stand for long time & $457(40.4)$ \\
\hline Type of psychological punishment & Number (\%) \\
\hline Shouted, yelled, and using language not acceptable & $224(19.8)$ \\
\hline Threatened to chase or spank & $145(12.8)$ \\
\hline Called out names like lazy, crazy, dumb, donkey, pig etc & $235(20.8)$ \\
\hline Compared with other students & $189(16.7)$ \\
\hline Listing out the mistakes in front of class & $175(15.5)$ \\
\hline
\end{tabular}


Table 4: Knowledge and perception regarding corporal punishment

\begin{tabular}{|c|c|c|c|}
\hline \multicolumn{4}{|c|}{ Knowledge regarding corporal punishment } \\
\hline & Girls $(n=525)$ & Boys $(n=605)$ & Statistical analysis \\
\hline Mean score of knowledge & $11.43 \pm 3.1$ & $10.9 \pm 3.5$ & $\begin{array}{l}\text { One way ANOVA } \\
\mathrm{F}(1,1130)=7.47 \\
\mathrm{P}=0.006\end{array}$ \\
\hline Good Knowledge (scored $>13$ ) & $210(40.0 \%)$ & $212(35 \%)$ & $\begin{array}{l}\text { Pearson's } \mathrm{X}^{2}(1,1130)= \\
2.95 \mathrm{P}=0.08\end{array}$ \\
\hline \multicolumn{4}{|l|}{ Knowledge factors* } \\
\hline Aware of the United nations charter & $446(84.9 \%)$ & $514(84.9 \%)$ & \multirow{5}{*}{$\begin{array}{l}\text { Pearson's X }{ }^{2}(4,5650)= \\
246.5 \quad \mathrm{P}<0.0001\end{array}$} \\
\hline Know the emergency number to call & $504(96 \%)$ & $558(92.2 \%)$ & \\
\hline CP is Illegal & $397(75.6 \%)$ & $457(75.5 \%)$ & \\
\hline $\mathrm{CP}$ affects the future & $398(75.8)$ & $415(68.6 \%)$ & \\
\hline $\mathrm{CP}$ is a punishable offence & $402(76.6 \%)$ & $426(70.4 \%)$ & \\
\hline \multicolumn{4}{|c|}{ Perception regarding corporal punishment } \\
\hline & Girls $(n=525)$ & Boys $(n=605)$ & Statistical analysis \\
\hline Mean score of attitudes $54.9 \pm 14.2$ & $54.9 \pm 13.4$ & $54.9 \pm 15.5$ & $\begin{array}{l}\text { One-way ANOVA } \\
(\mathrm{F} 1,1130)=0.01 \\
\mathrm{P}=0.9\end{array}$ \\
\hline \multicolumn{4}{|l|}{ Classification of perception score } \\
\hline Overall good feeling $(>85)$ & $10(1.9 \%)$ & $12(2.0 \%)$ & \multirow{3}{*}{$\begin{array}{l}\mathrm{X} 2(2,1130)=0.01 \\
\mathrm{P}=0.9\end{array}$} \\
\hline $\begin{array}{l}\text { More towards a positive perception } \\
(60-85)\end{array}$ & $214(40.7 \%)$ & $247(40.8 \%)$ & \\
\hline Change in perception is needed $(<60)$ & $301(57.3 \%)$ & $346(57.1 \%)$ & \\
\hline
\end{tabular}

${ }^{*}$ Cronbach alpha was 0.75 
Table 5: Mean Scores of perception of corporal punishment

\begin{tabular}{|l|l|}
\hline Perception factor & Mean \pm SD \\
\hline CP encourages you to study* & $2.8 \pm 1.3$ \\
\hline CP made me hate education & $2.9 \pm 1.4$ \\
\hline CP increases the capacity to study* & $2.9 \pm 1.3$ \\
\hline CP solves educational problems* & $2.1 \pm 1.0$ \\
\hline It increases the school attendance* & $2.5 \pm 1.2$ \\
\hline Has been useful to disciplines me & $2.9 \pm 1.3$ \\
\hline CP is the only mode to instill discipline* & $2.9 \pm 1.0$ \\
\hline Improves my personality* & $2.5 \pm 1.2$ \\
\hline CP promotes creativity* & $2.4 \pm 1.2$ \\
\hline CP increases a unity between friends & $2.2 \pm 1.2$ \\
\hline CP is always is beneficial* & $1.9 \pm 1.0$ \\
\hline Cp disgraces me & $2.4 \pm 1.3$ \\
\hline CP is painful and distressful & $2.5 \pm 1.3$ \\
\hline CP makes a good citizen later in life* & $2.6 \pm 1.2$ \\
\hline CP causes aggression in children & $2.5 \pm 1.3$ \\
\hline CP is psychologically beneficial* & $1.9 \pm 1.0$ \\
\hline CP has short term benefits & $3.1 \pm 1.9$ \\
\hline CP has long term benefits* & $2.5 \pm 1.1$ \\
\hline CP promotes future perpetrators to commit child abuse & $2.8 \pm 1.3$ \\
\hline CP increases the bond between Parent-child or teacher-student* & $2.2 \pm 1.1$ \\
\hline CP promotes an antisocial behaviour & $2.8 \pm 1.3$ \\
\hline CP promotes family disputes and GBV & $2.8 \pm 1.2$ \\
\hline
\end{tabular}


Table 6: Comparative analysis of perceived action to knowledge and perception scores

\begin{tabular}{|l|l|l|l|l|}
\hline $\begin{array}{l}\text { Perceived action } \\
\text { by the students }\end{array}$ & $\begin{array}{l}\text { Knowledge } \\
\text { Score }>\mathbf{1 3} \\
(\mathbf{n = 4 2 2})\end{array}$ & Statistical analysis & $\begin{array}{l}\text { Perception } \\
\text { Score }>\text { 60 } \\
(\mathbf{n}=\mathbf{4 8 3})\end{array}$ & $\begin{array}{l}\text { Statistical } \\
\text { analysis }\end{array}$ \\
\hline $\begin{array}{l}\text { Will take Legal } \\
\text { action } \\
(\mathbf{n}=\mathbf{9 0 0})\end{array}$ & $\begin{array}{l}400 \\
(94.7 \%)\end{array}$ & $\begin{array}{l}\mathrm{X}^{2}(1,1130)=95.2 \\
\mathrm{P}<0.0001\end{array}$ & $315(65.2 \%)$ & $\begin{array}{l}\mathrm{X}^{2}(1,1130) \\
=108.3 \\
\mathrm{P}<0.0001\end{array}$ \\
\hline $\begin{array}{l}\text { Favor complete } \\
\text { prohibition } \\
(\mathbf{n}=\mathbf{5 7 1})\end{array}$ & $\begin{array}{l}378 \\
(89.5 \%)\end{array}$ & $\begin{array}{l}\mathrm{X}^{2}(1,1130)=410.7 \\
\mathrm{P}<0.0001\end{array}$ & $213(44.0 \%)$ & $\begin{array}{l}\mathrm{X}^{2}(1,1130)=259.5 \\
\mathrm{P}<0.0001\end{array}$ \\
\hline $\begin{array}{l}\text { Prefer alternate } \\
\text { method of } \\
\text { discipline } \\
\text { (n=976) }\end{array}$ & $\begin{array}{l}396 \\
(93.8 \%)\end{array}$ & $\begin{array}{l}\mathrm{X}^{2}(1,1130)=31.9 \\
\mathrm{P}<0.0001\end{array}$ & $421(67.1 \%)$ & $\begin{array}{l}\mathrm{X}^{2}(1,1130)=0.44 \\
\mathrm{P}=0.5\end{array}$ \\
\hline $\begin{array}{l}\text { Accepted CP as } \\
\text { a mode of } \\
\text { discipline } \\
(\mathbf{n}=\mathbf{3 5 9})\end{array}$ & $85(20.1 \%)$ & $\begin{array}{l}\mathrm{X}^{2}(1,1130)=42.0 \\
\mathrm{P}<0.0001\end{array}$ & $198(40.9 \%)$ & $\begin{array}{l}\mathrm{X}^{2}(1,1130)=33.1 \\
\mathrm{P}<0.0001\end{array}$ \\
\hline $\begin{array}{l}\text { Detrimental to } \\
\text { future } \\
(\mathbf{n}=\mathbf{1 0 1 2})\end{array}$ & $\begin{array}{l}411 \\
(97.4 \%)\end{array}$ & $\begin{array}{l}\mathrm{X}^{2}(1,1130)=44.2 \\
\mathrm{P}<0.0001\end{array}$ & $408(84.5 \%)$ & $\begin{array}{l}\mathrm{X}^{2}(1,1130)=23.3 \\
\mathrm{P}<0.0001\end{array}$ \\
\hline
\end{tabular}

